\title{
Students' intention to join the hotel industry in Malaysia: the role of physical working conditions, pay and benefits, and promotion opportunities
}

\author{
Abdul alem Mohammed Mohammed \\ Shaqra University, Shaqra, Kingdom of Saudi Arabia \\ Faculty of Administrative Sciences, Taiz University, Taiz, Yemen
}

\begin{abstract}
Keywords
Physical Working Conditions Pay and Benefits, Promotion Opportunities, Intention to Join Industry.
\end{abstract}

\begin{abstract}
In Malaysia, little research has been published investigating hospitality graduates' justification for not joining the hotel industry. Therefore, the aim of this paper is to investigate the influence of physical working conditions, pay and benefits and promotion opportunities on students' intentions. A selfadministered questionnaire was used to gather data and measure respondents' perceptions, and a total of 102 hospitality students at University Utara Malaysia completed the survey. The study employed correlation and regression analyses to test the hypotheses. It was found that physical working conditions, pay and benefits, and especially promotion opportunities positively influence students' intention to join the hotel industry. Considering the positive impact of these factors, it is suggested that hoteliers should take initiatives to attract and motivate students to join their industry.
\end{abstract}

Corresponding author: Abdul alem Mohammed Mohammed

Email addresses for corresponding author: alemmohammed28@yahoo.com.my

First submission received: $29^{\text {th }}$ January 2018

Revised submission received: $14^{\text {th }}$ April 2018

Accepted: $3^{\text {rd }}$ May 2018

\section{Introduction}

Malaysia has been experiencing a steady growth in the tourism industry, with tourist expenditure increasing over the years. Specifically, statistics show that tourist arrivals increased between 2010 (RM24.58 million) and 2016 (RM26.67 million), with total receipts of RM82.1 billion (Tourism Malaysia, 2018). As the tourism and hospitality business has grown, there has been a corresponding increase in the need for skilled employees. One of the most serious challenges facing the hotel industry is attracting and retaining qualified and skilled staff.

Many studies have concluded that the fact that many hospitality management programme students lack an intrinsic willingness to enter this industry is one of the biggest challenges facing both the industry and educational institutions (Chang, Walsh \& Tse, 2014; Donina, 2015; Pizam, Okumus \& Hutchinson, 2013; Zopiatis \& Constanti, 2012). Richardson (2008) also concluded that many tourism and hospitality graduates fail to enter the industry after graduation due to poor working conditions, low job satisfaction and the absence of motivational factors. Furthermore, research to explore which factors are considered more important in students' career decisions highlighted that promotion and growth followed by working conditions were rated as the most important factors in selecting a hospitality career (McCleary \& Weaver, 1988). Kim, McCleary and Kaufman (2010) similarly found that opportunity for advancement is one of the most influential factors in career choice.

Despite the value of their results, previous studies (e.g., AkinAksu \& Deniz Köksal, 2005; Kusluvan \& Kusulvan, 2000; Richardson, 2008; Richardson \& Butler, 2012) only focus on students' perception and attitude toward careers in the tourism and hospitality industry. They do not examine the direct relationship of the factors (i.e. physical working conditions, promotion opportunities, and pay and benefits) and students' intention to join the hotel industry, a gap identified by Richardson (2009) as 
requiring more research. Studies in the Malaysian context are especially scarce (Ahmed, Rashid \& Mohd Shariff, 2014), although Richardson and Butler (2012) demonstrated that Malaysian tourism and hospitality students generally do not believe that a career in the industry will meet their requirements. Thus, the current study aims to explore the influence of physical working conditions, pay and benefits, and promotion opportunities on students' intention to join the hotel industry in Malaysia.

The remainder of this paper is organised as follows. The literature review concludes with establishment of the study hypotheses. Subsequent sections discuss the methodology, results and analysis, and discussion and implications. The final section presents the conclusion, limitations and suggestions for future studies.

\section{Literature review and development of hypotheses 2.1 Intention to join hotel industry}

The labour market in the hospitality industry is characterised by severe staff shortages and a high turnover (Felicen, Rasa, Sumanga, \& Buted, 2014). Not only is it difficult to attract new staff and retain hospitality and tourism students as employees (Waryszak, 1999), but a large number of the graduates pursue careers in other industries (Chang et al., 2014). Richadson and Butler (2012) stated that the hospitality industry does not offer the features to satisfy current students (potential employees), so it must adopt strategies and tactics to rectify the situation. In the following sections the study discusses factors that may encourage hospitality students to enter and remain in the industry.

\subsection{Physical working conditions}

Earle (2003) stated that organisations that understand how to use the physical work environment to achieve corporate objectives as well as provide employees with what they are looking for are actually thriving now more than ever before. The work environment is a major determinant in employee engagement or disengagement. Roelofsen (2002) indicated that improving the working environment reduces complaints and absenteeism while increasing productivity. There is adequate empirical evidence linking workplace conditions to job satisfaction (Newsham et al., 2009; Wells, 2000), including employees' comfort with the job (Mokaya, Musau, Wagoki \& Karanja, 2013). Physical working conditions may determine whether or not an individual fit a particular post (Naharuddin \& Sadegi, 2013). Jayaweera (2015) contended that working conditions have a significant effect on job performance in the hotel sector. Chen and Shen (2012) stated that physical working conditions play an important role in motivating employees to stay or leave the hospitality industry. Based on these arguments, the study proposes the following hypothesis:

H1. Physical working conditions have an influence on students' intention to join the hotel industry.

\subsection{Pay and benefits}

One of the tactics that can be used by employers to attract potential employees is a better reward and recognition system (Jauhari \& Manaktola, 2009). In this case, establishing equitable reward systems for staff and integrating a wide range of benefits are innovative recruitment and retention techniques (O'Leary \& Deegan, 2005). The hospitality industry is characterised by lower levels of pay than many other industries (Brien, 2004). Previous studies mentioned that the extrinsic reward factors play important roles in determining satisfaction with the students' career choice; salary and benefits were found to be the most significant positive (Lewis et al., 2001; Malka \& Chatman, 2003).

Furthermore, previous studies (e.g. AkinAksu \& Deniz Köksal, 2005; Richadson, 2008) have demonstrated that the pay and benefits factor can be considered as one of the barriers affecting students' intention to continue or pursue a career in the industry. Based on this discussion the study hypothesises the following:

H2. Pay and benefits have an influence on students' intention to join the hotel industry.

\subsection{Opportunities for promotion}

Undergraduate students are usually unsure of their future career path, and many studies have found that their work experience in the hotel industry identified poor treatment of employees, and few career promotion opportunities (e.g., Abdullah et al., 2015; Brown, Arendt \& Bosselman, 2014). 
The greater the achievement from finishing a challenging task, the greater the perceived feeling of recognition and responsibility; in turn, the greater the perceived opportunity for promotion and personal career development, and hence the greater commitment to their career, the more unlikely are individuals to move to another industry (Randolph \& Johnson, 2005).

In this case, Bao and Fang (2014) stated that the hotel industry should find some way of establishing a measurement for recognition of staff effort. They suggested giving a certificate or document acknowledging staff merit and performance and providing opportunities for promotion which can enhance the employees' sense of recognition and responsibility, in turn resulting in higher commitment to their career decisions to work in this industry.

Research exploring which factors are considered most important in students' career decisions identified promotion and growth, followed by working conditions, as the most important factors in selecting a career in hospitality (McCleary \& Weaver, 1988). Kim et al. (2010) agreed that the opportunity for advancement is especially influential. Investigating what motivates employees in the tourism industry, Yew (2007) found that the three most important factors are interesting work, job security and opportunities for advancement and development. Based on this discussion the following hypothesis is formulated:

H3. Opportunities for promotion have an influence on students' intention to join the hotel industry.

\section{Methodology}

A quantitative research approach was used, employing a self-administrated questionnaire. Convenience sampling was chosen, and questionnaires were administrated to 133 undergraduates enrolled in a hospitality programme at University Utara Malaysia (UUM). Questionnaires were distributed to the students in classrooms by the researcher and respective lecturers, during their presentation of the internship programme final report. Thirty-one questionnaires were incomplete, so the analysis was based on 102 responses.

The measurement of all three independent variables (i.e. physical working conditions, pay and benefits, and promotion opportunities) was derived from previous studies (Kusluvan \& Kusluvan, 2000; Richardson, 2008), and the measurement of the dependent variable (intention to join the industry) from Chang et al. (2014). Each item was measured using a 5-point Likert scale ranging from strongly disagree (1) to strongly agree (5).

\section{Results and analysis}

\subsection{Respondents' profile}

A frequency test was employed with all demographic and other related factors to obtain a profile of the respondents. $28.4 \%$ of the respondents were male and $71.6 \%$ female. Most were aged 24 or above $(96.1 \%)$ and the remaining $3.9 \%$ were in the $21-23$ group. $97.1 \%$ were from Malaysia and $2.9 \%$ were international students. All were currently on a half-year internship programme, with approximately $31.4 \%$ working in the front office, $29.4 \%$ in food and beverage, $27.4 \%$ in housekeeping, and $11.8 \%$ in sales and marketing.

\subsection{Assessing the reliability and validity of the instrument}

Using SPSS version 22, the reliability of the measurements was evaluated via Cronbach's alpha. The acceptable value of 0.70 or above (Field, 2009) was reached by all variables, thus all were considered as reliable and suitable for study. Factor analysis was used to test the validity of the instrument (Sekaran \& Bougie, 2010), and the results indicated they were valid.

\subsection{Relationship between physical working conditions, pay and benefits, promotion opportunities and intention to join the hotel industry}

Multiple regressions analysis used to investigate the influence of physical working conditions, pay and benefits, and promotion opportunities on students' intention to join the hotel industry. The model was significant $(\mathrm{F}=19.01 ; \mathrm{p}<.001)$ with predictors explaining $37 \%$ of the variation in intention to join the hotel industry. The three predictors significantly influence intention to join the industry. In terms of importance, promotion opportunities were the largest unique contributor to the intention to join the 
industry $(\beta=0.38 ; p<.001)$, followed by physical working conditions $(\beta=0.29 ; \mathrm{p}<.001)$ and pay and benefits $(\beta=0.20 ; p<.05)$.

\section{Discussion and Implications}

The results clearly demonstrate significant relationships between physical working conditions, pay and benefits, and promotion opportunities on students' intention to join the hotel industry. The findings are similar to those of Newsham et al. (2009), Wells (2000) and Mokaya et al. (2013), determining that workplace conditions enhance students' intention to join the tourism and hospitality industry. In order to attract the new talent emerging with Generation $Y$, it is imperative that companies adapt their physical environment to foster a more flexible and open culture (Earle, 2003). Management should consider creating a congenial work environment. A large proportion of new employees in the industry are teenagers who look forward to fun and pleasure in their work despite the repetitive nature of the job. In this case, Littlejohn and Watson (2004) stated that students and new graduates should approach the industry with a positive image of its promotion opportunities and working conditions, to encourage the best graduates to work in the industry. Regarding pay and benefits, the higher they are, the stronger the intention of students to pursue their career in the hotel industry. These results correspond with those obtained by Ahmed et al. (2012), who demonstrated that direct financial compensation and career choice intention were pull factors to join the hotel industry. The results of this study are in line with others (Chuang \& Dellman-Jenkins, 2010; Richardson, 2008; Kim et al., 2010) who demonstrated that opportunities for promotion may increase students' intention to join the tourism and hospitality industry. Our result is also consistent with Walsh and Taylor's (2007) data from hospitality alumni at their respective universities. "These researchers concluded that money alone does not motivate a young manager" (p.164); "one of the most important job features focuses on challenging job that offers growth opportunity" (p.179). Richardson (2008) also contended that the tourism and hospitality industry needs to handle the issue of promotion and career development in a more equitable way to attract graduates.

\section{Conclusion}

A number of findings emerged from this study. One important result was that promotion opportunity is one of the main factors that can influence students' intention to join the hospitality industry in Malaysia. Also, the findings generally agree that physical working conditions and pay and benefits have an influence on students' intentions. Undergraduate students are usually unsure of their future career path, and many studies have found that their work experience in the hospitality industry identified few career promotion opportunities, with insufficient rewards for effort (Abdullah et al., 2015; Brown et al., 2014; Chuang \& Dellmann-Jenkins 2010; Yiu \& Law, 2012). Therefore, hoteliers in Malaysia should offer suitable working conditions that satisfy the Y Generation's needs, with higher wages and benefits, and improved career paths to avoid losing these highly skilled and trained employees.

This study has some limitations. First, the convenience sampling method adopted by this research limited the generalisability of the findings. Therefore, expansion of the sample size and stratified random sampling procedures are recommended for future studies. Secondly, the study focused only on the direct influence of the three factors (i.e. physical working conditions, pay and benefits and promotion opportunities) on students' intention to join the hotel industry, therefore future studies can investigate moderating and mediation factors such as internship programmes and personal attitude on the relationships between the factors and students' intention to join the hotel industry.

\section{References}

Abdullah, R., Zahari, H., Mat, N.A.N., Zain, R.A. and Derani, N. (2015). Hospitality internships: an employment advantage or perilous experience. Journal of Basic and Applied Scientific Research, 5(8), pp.34-38.

Ahmad, N.A., Aziz, A.A., Yasin, S., Kamaruddin, A.A.A. and Bakhtiar, M.F.S. (2012). The Influence of Direct Financial Compensation towards Future-Graduates Career Choice in Hotel Industry. Unpublished Doctoral Thesis, Universiti Teknologi, Mara, Malaysia.

Akin Aksu, A. and Deniz Köksal, C. (2005). Perceptions and attitudes of tourism students in Turkey. International Journal of Contemporary Hospitality Management, 17(5), pp.436-447.

Ahmad, R., Rashid, B. and Mohd Shariff, N. (2014). Malaysian hospitality industry: Graduates' justifications for leaving the industry. International Journal of Management Studies (IJMS), 21(2), pp.1-20

Bao, Y.F., \& Fang, G.Y. (2014). A study on hotel students' satisfaction towards their internship: a case from Hang 
Zhou, China. International Journal of Contemporary Hotel Management,12, 1069-1076.

Brien, A. (2004). The New Zealand hotel industry-vacancies increase: While applicant numbers and caliber decrease. International journal of hospitality $\mathcal{E}$ tourism administration, 5(1), pp.87-104

Brown, E.A., Arendt, S.W. and Bosselman, R.H. (2014). Hospitality management graduates' perceptions of career factor importance and career factor experience. International Journal of Hospitality Management, 37, pp.58-67.

Chen, T.L., \& Shen, C.C. (2012). Today's intern, tomorrow's practitioner? The influence of internship programme on students' career development in the hotel industry. Journal of Hotel, Leisure, Sport E Tourism Education, 11(1), 2940.

Chang, S., Walsh, K., \& Tse, E.C.Y. (2014). Understanding students' intentions to join the hotel industry: the role of emotional intelligence, service orientation, and industry satisfaction. Cornell Hotel Quarterly, 56(4), 369-382.

Donina, A. (2015). The role of tourism and hotel companies in ensuring an effective internship process. Journal of Education Culture and Society, 2015(1), 281-290.

Earle, H.A. (2003). Building a workplace of choice: Using the work environment to attract and retain top talent. Journal of Facilities Management, 2(3), pp.244-257.

Jayaweera, T. (2015). Impact of Work Environmental Factors on Job Performance, Mediating Role of Work Motivation: A Study of Hotel Sector in England. International Journal of Business and Management; 10(3), pp.271-278.

Walsh, K., Chang, S. and Tse, E.C.Y. (2015). Understanding students' intentions to join the hospitality industry: The role of emotional intelligence, service orientation, and industry satisfaction. Cornell Hospitality Quarterly, 56(4), pp.369-382.

Chuang, N.K. and Dellmann-Jenkins, M. (2010). Career decision making and intention: A study of hospitality undergraduate students. Journal of Hospitality $\mathcal{E}$ Tourism Research, 34(4), pp.512-530.

Felicen, S.S., Rasa, L.C., Sumanga, J.E. and Buted, D.R. (2014). Internship performance of tourism and hospitality students: Inputs to improve internship program. International Journal of Academic Research in Business and Social Sciences, 4(6), p.42.

Field, A. (2009). Discovering statistics using SPSS for windows. London: Saga Publication.

Jauhari, V. and Manaktola, K. (2009). Managing workforce issues in the hospitality industry in India. Worldwide Hospitality and Tourism Themes, 1(1), pp.19-24.

Kim, B.P., McCleary, K.W. and Kaufman, T. (2010). The new generation in the industry: Hospitality/Tourism students' career preferences, sources of influence and career choice factors. Journal of Hospitality $\mathcal{E}$ Tourism Education, 22(3), pp.5-11.

Kusluvan, S. and Kusluvan, Z. (2000). Perceptions and attitudes of undergraduate tourism students towards working in the tourism industry in Turkey. Tourism management, 21(3), pp.251-269.

Leather, P., Pyrgas, M., Beale, D. and Lawrence, C. (1998). Windows in the workplace: Sunlight, view, and occupational stress. Environment and behavior, 30(6), pp.739-762.

Lewis, D., Brazil, K., Krueger, P., Lohfeld, L., \& Tjam, E. (2001). Extrinsic and intrinsic determinants of quality of work life. Leadership in Health Services, 14(2), 9-15.

Littlejohn, D. and Watson, S. (2004). Developing graduate managers for hospitality and tourism. International Journal of Contemporary Hospitality Management, 16(7), pp.408-414.

Malka, A., \& Chatman, J.A. (2003). Intrinsic and extrinsic work orientations as moderators of the effect of annual income on subjective well-being: alongitudinal study. Personality and Social Psychology Bulletin, 29(6), 737-746.

McCleary, K.W. and Weaver, P.A. (1988). Expectations of hospitality students regarding entry level positions in the hospitality industry. Hospitality Education and Research Journal, 12(2), pp.163-174.

Mokaya, S.O., Musau, J.L., Wagoki, J. and Karanja, K. (2013). Effects of organizational work conditions on employee job satisfaction in the hotel industry in Kenya. International Journal of Arts and Commerce, 2(2), pp.79-90.

Naharuddin, N.M. and Sadegi, M. (2013). Factors of workplace environment that affect employee's performance: A case study of Miyazu Malaysia. International Journal of Independent Research and Studies, 2(2), 66-78.

Newsham, G., Brand, J., Donnelly, C., Veitch, J., Aries, M. and Charles, K. (2009). Linking indoor environment conditions to job satisfaction: a field study. Building Research E Information, 37(2), pp.129-147.

O'Leary, S. and Deegan, J. (2005). Career progression of Irish tourism and hospitality management graduates. International Journal of Contemporary Hospitality Management, 17(5), pp.421-432.

Pizam, A., Okumus, F., \& Hutchinson, J. (2013). Forming a long-term industry-university partnership: the case of Rosen College of Hotel Management. Worldwide Hotel and Tourism Themes, 5(3), 244-254.

Randolph, D.S. and Johnson, S.P. (2005). Predicting the effect of extrinsic and intrinsic job satisfaction factors on recruitment and retention of rehabilitation professionals. Journal of Healthcare management, 50(1), p.49

Richardson, S. (2008). Undergraduate tourism and hospitality students' attitudes toward a career in the industry: A preliminary investigation. Journal of Teaching in Travel $\mathcal{E}$ Tourism, 8(1), pp.23-46.

Richardson, S. (2009). Undergraduates' perceptions of tourism and hospitality as a career choice. International Journal of Hospitality Management, 28(3), pp.382-388. 
Richardson, S. and Butler, G. (2012). Attitudes of Malaysian tourism and hospitality students towards a career in the industry. Asia Pacific Journal of Tourism Research, 17(3), pp.262-276.

Roelofsen, P. (2002). The impact of office environments on employee performance: The design of the workplace as a strategy for productivity enhancement. Journal of facilities Management, 1(3), pp.247-264.

Sekaran, U. and Bougie, R. (2016). Research methods for business: A skill building approach. John Wiley \& Sons.

Tourism Malaysia. (2018). Tourism Malaysia-Statistics. Retrieved April 3, 2018, from. http:/ / www.tourism.gov.my/statistics

Yew, L.T. (2007). Job satisfaction and affective commitment: A study of employees in the tourism industry in Sarawak, Malaysia. World Review of Entrepreneurship, Management and Sustainable Development, 4(1), pp.85-101.

Yiu, M. and Law, R. (2012). A review of hospitality internship: Different perspectives of students, employers, and educators. Journal of Teaching in Travel E Tourism, 12(4), pp.377-402.

Walsh, K. and Taylor, M.S. (2007). Developing in-house careers and retaining management talent: What hospitality professionals want from their jobs. Cornell Hotel and Restaurant Administration Quarterly, 48(2), pp.163-182.

Waryszak, R.Z. (1999). Students' expectations from their cooperative education placements in the hospitality industry: an international perspective. Education+ Training, 41(1), pp.33-40.

Wells, M.M. (2000). Office clutter or meaningful personal displays: The role of office personalization in employee and organizational well-being. Journal of Environmental Psychology, 20(3), pp.239-255.

Zopiatis, A., \& Constanti, P. (2012). Managing hotel internship practices: a conceptual framework. Journal of Hotel $\mathcal{E}$ Tourism Education, 24(1), 44-51. 